\title{
Hvordan kan vi lære barn å mestre livet?
}

\author{
Av Anne Greve \\ Professor i barnehagepedagogikk, OsloMet - storbyuniversitetet. \\ E-post: anne.greve@oslomet.no
}

Det har kommet inn et nytt begrep i barnehagens styringsdokumenter: livsmestring. Tidligere snakket man om livsglede, i hvert fall i barnehagens rammeplan. Jeg er en av dem som er kritisk til denne endringen - fra glede til mestring. Jeg vil i denne artikkelen stille spørsmålet: Hva innebærer det at livet går fra å være noe vi skal glede oss over, til å bli noe vi skal mestre?

I rammeplanen for barnehagens innhold finner vi allerede i første kapittel følgende utsagn: Barnehagen skal fremme demokrati, mangfold og gjensidig respekt, likestilling, bærekraftig utvikling, livsmestring og helse (Rammeplan for barnehagen, 2017, s. 3). Senere i planen er livsmestring viet et eget kapittel: Livsmestring og helse. Men selve begrepet livsmestring blir lite brukt ut over denne overskriften. Derimot er det mye snakk om mestring.

En utfordring med begrepet livsmestring er at det er vanskelig, for ikke å si umulig, å vite hva det faktisk innebærer. Mestring er avledet av begrepet mester. Mester er en overordnet, i Bibelen brukes det om Kristus, men i dagligtale bruker vi det gjerne om en person som er svært dyktig til noe, eller om en håndverker med mesterbrev. Det er unektelig en positiv klang over det å mestre noe. Det handler om å få til, å lykkes - noe som igjen er nært knyttet til følelsen lykke. Det handler også om å fă til noe som vi har strevd litt med. Vi kan vel alle kjenne oss igjen i den gode lykkefølelsen man kan få dersom man mestrer noe etter å ha strevd en del i forkant. Men hva er forskjellen på å mestre noe og å bare få det til? Og hva innebærer det å mestre livet?

Mestringsbegrepet er i rammeplanen gjennomgående knyttet opp til helse. I tilknytning til læring og progresjon snakkes det om utfordringer og mestringsopplevelser. Barnet skal oppleve mestring i forbindelse med fagområdet Kropp, bevegelse, mat og helse, mens personalet skal anerkjenne barnets mestring her. Mestringsbegrepet blir fulgt opp med en film, utarbeidet av Utdanningsdirektoratet (UDIR, 2017). Også filmen vektlegger fysisk aktivitet og helse i forbindelse med mestring. Førsteamanuensis Monica Seland fra DMMH forteller her om mestring, og vektlegger mestring som en positiv følelse av å lykkes og å få til noe, og at denne følelsen er en viktig motivasjon for videre læring. Slik sett kan det synes noe merkelig at mestringsbegrepet ikke også blir satt i forbindelse med de andre fagområdene i rammeplanen: kommunikasjon,

Prismet - IKO-Forlaget 2019

Tilgjengelig på https://journals.uio.no/index.php/prismet Publisert under CC BY-NC 4.0. Årgang 70, hefte 1, s. 47-52 
språk og tekst; kunst, kultur og kreativitet; natur, miljø og teknologi; antall, rom og form; etikk, religion og filosofi; nærmiljø og samfunn. Det er altså bare innenfor fagområdet kropp, bevegelse, mat og helse at barn skal oppleve mestring.

Hvis vi ser nærmere på hvor begrepet livsmestring kommer fra, er det lettere å forstå denne koblingen til kropp og helse. Verdens helseorganisasjon (WHO, 2003, s. 3) bruker begrepet life skills og definerer det slik: Life skills are abilities for adaptive and positive behaviour that enable individuals to deal effectively with the demands and challenges of everyday life. Individet skal gjøres i stand til å ta gode og velfunderte valg som kan bidra til å løse problemer, tenke kritisk og kreativt og føre et liv som er både sunt og produktivt. Når begrepet livsmestring har kommet inn i både skolens og barnehagens styringsdokumenter, stilles det ganske store krav både til det enkelte barnet og til lærere som skal sørge for at barnet når dette målet. Livet går fra å være noe som skal leves og glede seg over, til å bli noe som må presteres.

Konsekvensene av å ikke mestre livet, synes å være ganske kritiske. Derfor blir det viktig for samfunnet å arbeide på flere fronter, både å styrke de som allerede mestrer livet (helsefremmende), å forebygge at noen faller utenfor og å avhjelpe de som allerede har utfordringer med å klare å mestre livet. I kjølvannet av denne tankegangen får vi begreper som tidlig innsats. Men i et samfunn der bekymringen er at for mange faller utenfor, kan det være betimelig å stille spørsmålet om det er for mange mennesker som har problemer, eller om det er samfunnets krav til oss som har blitt for store og at den plattformen vi må holde oss innenfor for ikke å falle av, blir for smal. Anthony Giddens (1999, s. 3) var allerede før årtusenskiftet opptatt av at samfunnet vårt er blitt et risikosamfunn der vi i stadig st $ø$ rre grad er opptatt av sikkerhet og forebygging av fremtidige risikoer. Ingemar Engström (2017, s. 13) skriver om den svenske skolen at det tidligere var et hovedmål å fremme barns psykiske helse og utvikling, men at det nå i stadig større grad blir en oppgave å forebygge ulike helseproblemer. Det er grunn til å tro at vi kan se den samme utviklingen i vårt land, i takt med at livsmestringsbegrepet ikke bare făr en plass i skolens, men også kommer inn i barnehagens styringsdokumenter. Men fordi det er så vanskelig å definere hva livsmestring faktisk er, blir det mulig for mange ulike aktører å lage definisjonen. Dermed åpnes det opp for diverse diagnostiserings-, forebyggings- og tidliginnsatsverktøy og -programmer. Først må det kartlegges hvilke problemer ulike barn kan slite med for å oppnå livsmestring. Både i skolen og barnehagen har vi sett en oppblomstring av ulike kartleggingsverkt $\varnothing y$ (Greve, 2015, s. 204). Dernest blir det tilbudt spesielle programmer som kan bøte på de utfordringene som avdekkes. Et annet alternativ er å hoppe over kartleggingen og gå rett på spesielle programmer som skal styrke barns livsmestring, som barns psykiske helse 
og psykososiale kompetanse. Slike programmer følger gjerne en spesiell metode for å nå et definert mål som er bestemt på forhånd. Fordi det som regel kreves at brukerne av programmet holder seg strikt til fremgangsmåten og progresjonen i programmet, innsnevrer bruk av slike programmer den pedagogiske friheten til lærerne (Engström, 2017, s. 15). Lærerne som skal bruke programmet, må kurses i hvordan programmet skal brukes, for å sikre at alle gjør det «riktig». Jeg kjenner ikke til at det er noen statistikk over hvor mange barnehager og skoler som følger slike programmer, men Engström (2017, s. 15) fastslår at det er en stigende tendens i Sverige, og det er ingen grunn til å tro at det er annerledes i Norge. Jeg tror at det kan ha sammenheng med at livsmestringsbegrepet har kommet så sterkt inn i styringsdokumentene, fordi programmene tilsynelatende tilbyr en løsning på et noe diffust problem.

En side ved den norske barnehagetradisjonen som jeg mener vi har grunn til å være stolte over, har vært at alle har vært velkomne i barnehagen. Norske barnehager har vært åpne for alle barn, uavhengig av funksjonsevne og bakgrunn. Helt frem til full barnehagedekning ble lovfestet i 2009, var det faktisk slik at barn med ulike spesielle utfordringer ble prioritert ved opptak. Kom som du er, du er bra nok. Da var det ingen som snakket om livsmestring, men at alle skulle få mulighet til å utvikle seg, leke og lære ut fra egne premisser. I motsetning til mange andre land i Europa, har vi i Norge hatt svært få spesialbarnehager (Korsvold, 2011, s. 13). Tradisjonell barnehagepedagogikk tar utgangspunkt i barnet der det befinner seg, og arbeider med videre utvikling ut fra barnets evner og interesser. Dersom barnehagen nå er på vei til å måle barna ut fra forhåndsbestemte kriterier, for så å oppdage «feil» eller «mangler» som kan stå i veien for barns livsmestring, mener jeg vi er på vei i feil retning. Jeg synes den utbredte bruken av standardiserte programmer kan virke som en indikasjon på at vi beveger oss i denne retningen.

Slik jeg ser det, er det mange problemer knyttet til bruken av slike programmer. For det første er det nødvendig å se på hvilket samfunnsoppdrag barnehagen har og om programmer kan være med på å fremme dette samfunnsoppdraget. I tillegg til at barnehagen skal styrke barns livsmestring, skal barnehagen også, som vist innledningsvis i denne artikkelen, fremme demokrati, mangfold og gjensidig respekt, likestilling, bærekraftig utvikling. Dette er et vidt mandat som krever en vid inngang. Monica Seland (2017, s. 90-110) trekker frem et mye brukt program, «De utrolige årene», som et eksempel på hva bruk av programmer kan bety sett i relasjon til barnehagen som en lærende organisasjon. Hun diskuterer i den forbindelsen forskjellen på det å være uenig og det å være ulydig. Hvis man er uenig, er det et uttrykk for at man som en aktiv akt $ø$ r bruker sin rett til å stille seg kritisk til ett eller annet. Et barn som blir karakterisert som å være uenig, får status som et meningsbærende subjekt med rett til å gi uttrykk 
for sine synspunkter. Dette synes å være helt i tråd med samfunnsmandatet om å fremme demokrati, mangfold og gjensidig respekt. Et barn som derimot blir karakterisert som ulydig, slik det gjøres i programmet «De utrolige årene», blir tildelt en helt annen rolle. Et ulydig barn er ikke et aktivt subjekt med rett til egne meninger og rett til å ytre seg. Et ulydig barn er en person som ikke vil innordne seg det en autoritet (en barnehagelærer) bestemmer. Skal barn lære å mestre livet i et demokratisk samfunn, innebærer det, slik jeg ser det, at barn lærer at det er rom for å kritisere og uttrykke både enighet og uenighet.

For det andre viser det seg at mange av programmene som blir tilbudt norske barnehager, er utviklet med tanke på å hjelpe spesielle barn med helt spesielle problemer. Et eksempel er ART (Aggression Replacement Training), som er utarbeidet med tanke på å hjelpe barn og ungdom med store atferdsvansker, utprøvd i amerikanske ungdomsfengsler (Pettersvold \& Østrem, 2012). Selv om programmet gjennomgår en tilpasning til norske forhold, er det grunn til å tro at slike programmer ikke passer i en norsk barnehagekontekst. Tanken er nok at det som hjelper på barn og ungdom som har store problemer, sannsynligvis også vil ha en effekt på andre barn - om ikke annet som et forebyggende virkemiddel og for å styrke livsmestring. Jeg er ikke enig i en slik tankegang. Barn og unge med store atferdsproblemer må øve på ting som faller naturlig for andre barn. Det blir derfor feil å sluse alle barn inn i et treningsopplegg som er beregnet på noen få. De fleste barn trenger ikke å trene på å erstatte sin aggresjon med noe annet, slik navnet på programmet indikerer. Tvert imot kan det være bra for barn å vise sinne og motstand hvis de føler seg urettferdig behandlet.

For det tredje er det et problem med forståelsen av at noe skal «virke». Da blir spørsmålet: virke for eller mot hva? Dette spørsmålet er ikke lett å besvare uten å se på hvilke verdier vi ønsker skal ligge til grunn for barns utdanning og mestring av livet. Flere programmer som skal fremme barns sosiale utvikling, for eksempel PALS (Positiv Atferd, Støttende Læringsmiljø og Samhandling), gir barn belønning - på samme måte som Pavlovs hunder fikk - i form av imaginære kakestykker eller lignende når barna gjør noe som programmet vurderer som bra. Dette strider helt imot de demokratiske verdiene barnehagens tradisjon står for, og som er nedfelt i lovverk og rammeplan. Barn som viser motstand, risikerer å ikke få kakestykkene sine i programmer som PALS, eller å bli kategorisert som «aggressive» i programmer som «De utrolige årene» (De utrolige årene, 2015). Programmene tar ikke hensyn til hvilket barn det er snakk om eller konteksten barnet befinner seg i. Det levnes lite eller ikke noe rom for profesjonelt skjønn.

Verdens helseorganisasjon er opptatt av at barn skal lære å føre et sunt liv. Et sunt og produktivt liv knyttes opp mot livsmestring (WHO, 2003, s. 3). Et pågående forskningsprosjekt (Children at 'risk') sammenligner norske og franske 
barnehager med siktemålet å få $\emptyset \mathrm{kt}$ forståelse for hva henholdsvis norske og franske barnehagelærere opplever som risikofylt. Resultatene viser blant annet at hva som vurderes som sunt, i stor grad er kulturelt betinget. Mens for eksempel de norske barnehagelærerne mener det er sunt for barn å drikke melk, frykter de franske at dette kan føre til hjerte- og karsykdommer senere i livet. De franske barnehagelærerne er også bekymret for den store mengden brødmat som de norske barna får. De norske barnehagelærerne er på sin side overrasket over at franske barn får sukkerholdige desserter hver dag. Her mener de norske at det er stor sannsynlighet for at barna kan få både sukkersyke og dårlig tannhelse (Greve m.fl. under utgivelse). Det er altså ikke gitt en gang for alle hva som er sunt. Der mange programmer søker etter evidensbasert kunnskap (hva som virker), viser forskning at det er andre type spørsmål som bør stilles, som å søke forståelser, forklaringer, kritikk eller tolkninger (Engström, 2017, s. 16). Livet er komplisert og mangfoldig. Derfor finnes det ikke enkle løsninger. Det er også grunnen til at jeg stiller meg kritisk til overgangen fra begrepet livsglede til livsmestring i barnehagens styringsdokumenter. Jeg mener det innebærer en fare for at oppmerksomheten i for stor grad blir rettet mot forebygging og dermed problematferd, og at dette strider mot det som er barnehagens og skolens samfunnsmandat. Jeg mener videre at livsmestring i for stor grad peker mot prestasjoner og spesielle krav, på bekostning av anerkjennelse og aksept av mangfold.

Jag vill takka livet, som gett mig så mycket, synger Arja Saijonmaa. Jeg ser også på livet som en gave - en gave som gir mange muligheter, utfordringer, forventninger, men i tillegg skuffelser og sorger. Også det siste er med på å berike livet. Det er kanskje særlig når vi har måttet streve litt, at lykkefølelsen kan bli ekstra stor når vi får til noe, når det er noe vi mestrer. Slike mestringsopplevelser er det viktig at vi legger til rette for at barn både i skole og barnehage får oppleve i så stor grad som mulig. Men selve livet - det skal vi slippe å streve med å mestre. Det skal vi bare glede oss over.

\section{LITTERATUR}

De utrolige årene (2015). http://dua.uit.no/wp-content/uploads/2017/12/87479_brosjyre_RKBU_2017_111217.pdf

Engström, I. (2017). «En värdefull skola.» I: I. Engström (red.). Skolans arbete med elevers psykiska hälsa (s. 9-22). Malmö: Gleerups.

Giddens, A. (1999). Risk and responsibility. The modern law review, 62(1), 1-10.

Greve, A. (2015). «Barnehagelærerprofesjonens utfordringer i møte med politiske forventninger om læringsutbytte.» I: B.A. Hennum, M. Pettersvold \& S. Østrem (red.) Profesjon og kritikk (s. 201-219). Bergen: Fagbokforlaget.

Greve, A. m.fl. (under utgivelse). «Food and constructions of risk in Norwegian and 
French kindergartens.» European Early Childhood Education Research Journal.

Korsvold, T. (2011). «Barndom - barnehage - inkludering.» I: T. Korsvold (red.)

Barndom - barnehage - inkludering (s. 9-31). Bergen: Fagbokforlaget.

Pettersvold, M. \& Østrem, S. (2012). Virkninger og bivirkninger av pedagogiske programmer. Barnehagske betraktninger. http://www.barnehagskebetraktninger. no/2012/04/virkninger-og-bivirkninger-av.html

Seland, M. (2017). «Uenig eller ulydig? Barns motstand i en lærende organisasjon.» I: M. Øksnes \& M. Samuelsson (red.) Motstand. Barndom i barnehagen (s. 90-114). Oslo: Cappelen Damm Akademisk.

UDIR (2017). Film: Mestring i barnehagen. https://www.udir.no/laring-og-trivsel/ stottemateriell-til-rammeplanen/film-mestring-i-barnehagen/

WHO (2003). Skills for health. Information series of school health, document 9. Atlanta, Georgia, USA. 